\title{
Prediction of Bankruptcy Risk: Evidence from Listed Manufacturing Companies in Sri Lanka
}

\author{
K. M. S. Senevirathne \\ University of Moratuwa, Sri Lanka \\ G. N. Kuruppu \\ University of Moratuwa, Sri Lanka
}

\begin{abstract}
The past experience in number of industries evidenced that even healthy companies can bankrupt and abolish stakeholder confidence while creating a significant damage to country's economy. Though stakeholders are vulnerable, how they can assess the bankruptcy level is another question that researchers are trying to answer. This creates an urgency to find out the bankruptcy level of manufacturing companies in Sri Lanka using an appropriate model and publicly available information in order to protect stakeholders. Therefore, the objective of the study is to investigate the degree to which bankruptcy risk can be predicted from the business performance of listed manufacturing companies in Sri Lanka. Quantitative approach has been applied in the study align with the ZETA model. Secondary data was used in this study which gathered through the annual reports and the data was analysed through e-views 6 software. The study found that bankruptcy risk can be identified from financial performance and non-financial performance. The finding of the study benefits the different stakeholders to make decisions relevant to manufacturing firms in Sri Lanka.
\end{abstract}

\section{Corresponding Author:}

Mr. K. M. S. Senevirathne is a Lecturer at the Faculty of Business, University of Moratuwa, Sri

Lanka. E-mail: manulas@uom.lk 


\section{Keywords}

Bankruptcy risk, Business performance, Manufacturing companies, ZETA model

\section{Introduction}

In way back in the $19^{\text {th }}$ century traditional ratio analysis was considered as a technique which is used by the practitioners to analyse the business performance and risk of their business decision making (Altman, 1968). The most common and available source was annual reports which can perform ratio analysis to assess the status of the company (Sandin \& Porporato, 2007) by any stakeholder. However, Altmen (1968) emphasized that it is doubtful whether ratio analysis can be used as an analytical technique to future bankruptcy of companies. Based on different arguments many scholars developed different models to test the bankruptcy risk of a company. Altman's ZETA model or rather Z-score model along with discriminant analysis was one of the best and widely used models, which recognises the bankruptcies in companies (Altman, 1968).

However, when focusing on the context, there are enough local and international evidence within last decades to prove that companies can become financially insolvent and bankrupt due to many reasons, such as aggressive expansion of operations, mismanagement, and high level of financial gearing (Colombo Stock Exchange [CSE], 2009). Similarly, in the international context Lehman Brothers, AG, Washington Mutual, and Fannie Mae \& Freddie Mac and in the local context, Prarnuka Bank and Golden Key were bankrupt and Seylan Bank and The Finance Company Limited had created a doubt among general public. Unfortunately, many of these companies were unable to assess their financial conditions prior to their failures. On the other hand, other stakeholders like creditors, investors, and shareholders were not in a position to assess these companies' solvency before the tragedy happens. These incidents seriously affect the country's economy and lose the investor and stakeholder confidence (Gnanaweera, 2011). According to Bum (2007), identifying risk of bankruptcy is vital as when a company is suffering with financial distress situation and there is a problem for the employees of such company as well as for the shareholders, lenders, and the other stakeholders. It is critical for job security of managers and employees, stakeholders' equity position, and claims of lenders since 
their claims are not guaranteed. This evidence provides the need of assessing the financial health of the companies more effective manner in order to ensure the economic stability of the country while ensuring the stakeholder interest.

Recent reports confirm that Sri Lankan manufacturing sector plays an important role in economic growth of the country and many manufacturing firms are showing significant growth after end of the civil war in 2009. As a result, most of the investors in the Sri Lankan stock market prefer to invest in manufacturing firms listed in the CSE. Hence, it is vital to promote manufacturing firms (Thusyanthi \& Yogendrarajah, 2016) which are also vulnerable for bankruptcy. However, investors have the same problem in identifying the industries and firms, which are not performing well and companies, which are vulnerable to bankrupt (Appiah \&Abor 2009). This situation becomes worse as even financially sound companies can be bankrupted (Ong, Yap, \& Khong, 2011). Predominantly it was a question whether the financial statements provide the proper guidance to identify the risk. Therefore, the financial and non-financial performance of the companies needs to be addressed. Further, as stated by Gnanaweera (2011) there is a deficiency in the Sri Lankan context to evaluate the soundness of the Z-score model for bankruptcy prediction in Sri Lanka. Therefore, this study will investigate to what extend the bankruptcy risk can be predicted through business performance of listed manufacturing companies in CSE.

Therefore, the research objective of this study is to explain the relationship between bankruptcy risk and the business performance of listed manufacturing companies in Sri Lanka.

\section{Literature Review}

\section{Bankruptcy Risk}

Bankruptcy is an economic indicator, which is common to both developed and developing countries that perform in any industry. This has an impact on many people hence has gained much public attention. This is the declared inability or impairment of the ability of an individual or organisation to pay its creditors. The concept and the origin of bankruptcy law have been originated in England. A commercial law practitioner, an attorney at law, mentioned that the law relating to bankruptcy is based 
mainly on the English Law. There is provision in the Sri Lankan law for persons to have themselves declared bankrupt by court in the event if they are unable to settle their debts. These are called as pauper actions and were found in Sections 442 to 449 of the Civil Procedure Code. However these sections were repealed by Act No: 20 of 1977.

Importantly, Abor, Saprong-Kumankoma, Fiawoyife, and Osei (2009) have emphasized that risk has been identified as a major factor in financial decisions. Empirical and theoretical research do not provide proper answer regarding the debt level and capital structure where capital structure of the firm plays a pivotal role in deciding integrated risk of a firm. Moreover, Sandin and Porporato (2007) explained that univariate studies which focus on the ratios on categories of earnings, liquidity, and solvency are very much important to decide the bankruptcy.

Focusing on international context, the firms operate in many developed countries like United State of America (USA) are voluntary declare as a bankrupted company in order to gain some advantages such as borrow more money and take time to solve the problems. However, this is still new to the Sri Lankan contest and it will take a longer period to declare as a bankrupt. Furthermore, in Sri Lankan terms it is different, empirically, due to the market fact that the number of companies de-listed by the CSE due to bankruptcy or liquidity issues is very low during the last decades. There are only a few business failures declared in public for many years (Gnanaweera, 2011). Therefore, it is clear that we need to concern about the bankruptcy risk and inform the public in advance through the predictions that can be made as per the Z-score model.

\section{ZETA Model (Z-score model)}

Specifically, it is difficult to identify financially healthy businesses to invest since there is no recognised model to identify the risk. Thus, the objective of ZETA model was to develop a suitable method to identify the bankruptcy risk of the companies focusing on the multiple discriminant analysis (Appiah \& Abor, 2009). Moreover, bankruptcy risk of the economies can be identified through financial health, financial troubles, bankrupt level, and liquidity level (Stickney, 1990 as cited in Sandin \& Porporato, 2007). Apart from that, Lee and Yeh (2004) have explained that weak corporate 
governance results high probability of financial distress compared to firms practice proper corporate governance, which imply the importance of qualitative improvements of a business.

Initially, as Altman, Haldeman and Narayanan (1977) have explained that with the recent development of the business failure models, ZETA has been developed to predict the bankruptcy risk five years in prior in manufacturing companies and retailers. The reasons for developing this model states that there were failures in business based on the financial profile; model should be temporal due to changing nature of the data, past models concentrated on a particular industry, most recent changes in financial and accounting aspect which has been considered to develop the model, and finally lots of modifications have been done as suitable to the present context. As Altman (1968) emphasized, number of financial ratios have been taken into consideration in this model as profitability, liquidity, leverage, solvency, and activity. To select the appropriate rations, statistical significance, inter correlations between the variables, accuracy, and judgment of the analysis have been considered. More specifically, areas concerned under the model can be mentioned as follows.

- X1: best ratio which consider the liquidity and size characteristics explicitly

- X2: which concern about the cumulative profitability

- X3: earning power of assets is concerned by ignoring leverage factors

- X4: firm's assets decline before liabilities exceeds the asset value.

- X5: sales generating capability of assets is conserned

Finding of the study explains that when $\mathrm{Z}>2.99$, the company is safe; $1.8<\mathrm{Z}>2.99$, the company is in grey zone while $\mathrm{Z}<1.8$, it is financially distressed. Further, in Altman's model the highest contribution was profitability ratio while the lowest was working capital (Appiah \& Abor, 2009). According to this model business is focused under five main areas its status can be identified.

Moreover, there are number of studies that can find international context in the area of predicting financial distress. Samarakoon and Hasan (2003) empirically tested the three versions of Altman's Z-Score model with 
the financially distressed companies in Sri Lanka. According to them the USA based Altman Z-Score model has a remarkable degree of accuracy in predicting distress in the year prior to distress. This study has concluded that the Z-Score model is a suitable model in predicting financial distress in Sri Lanka.

\section{Evolution of Z-score Model}

As Sandin and Porporato (2007) explained, in early days unemployment and social pressure, which affect the economy and globalization have created considerable outcomes in the business environment. However, the reforms, which include the diversification of business were appropriate for the prevailing legal setup. Aligning to this Altman (1968) has mentioned that when they make the diversification decisions, they require an analysis which considers the items with same characteristics in a single particular group.

Later on, Multiple Discriminant Analysis (MDA) has been introduced in 1930, which has used to attain financial problems such as credit evaluation and investment classification. The model developed under MDA was Zscore model, which classifies the bankruptcy prior to five years on 70 per cent accuracy and further alternative bankruptcy prediction can be made by using the expected cost criteria (Altman et al., 1977). Importantly, ZETA is the most pioneering model developed to test the going concern (Young \& Wang, 2010). Thereafter most of the industries have been utilized the model to make the future predictions.

According to Sandin and Porporato (2007), this is an intuitive strategy to compare the groups with similar and dissimilar characteristics with others. However, the classification of bankruptcy models is based on the stage of the company at a particular situation. Further, the industry type also plays an important role when it comes to bankruptcy prediction, which is a most used method to discover the failures.

Specifically, Altman et al (1977) specified that to develop the model the following important aspect has been considered namely capitalization of leases, reserves, minority interest and other liabilities, captive finance companies and non-consolidated reserves, goodwill, and capitalized 
research. Basically this model has concerned on seven variables under multivariate statistical technique.

In Sri Lanka, Samarakoon and Hasan (2003) have examined the original Altman's Z-score models and have concluded that the third version of score model (Z-score model) gives the highest overall success rate and it seems that Z-score models have a very good potential in predicting. The most prominent model developed based on companies in the United Kingdom and all the variables used are different from Altman's Model. Finally, it can conclude that the Z-score model under MDA is still a valid model for predicting financial distress in the Sri Lanka context though there are criticisms over MDA (Nanayakkara \& Azzez, 2015). Specifically, as Altman (1968) mentioned unfavourable credit risk can be measured through the MDA. However, he further explained that just a numerical value is not sufficient to make a decision about a particular company. Similarly, Z-score model helps investors and bankers for decision making under unstable economic conditions (Sandin \& Porporato, 2007). Furthermore, Appiah and Abor (2009) have revealed that Altman's model can be used for credit evaluation and portfolio evaluation as internal control guidance.

Significantly, ratio analysis has found important for financial institutions for their lending decisions. The main concern there is to measure the creditworthiness of the customer when providing loans to customers. However, the financial distress of bank is not concerned in such situations, which should be addressed mostly. Likewise, the validity of Z-score model affects number of parties to make better decisions while minimizing the risk.

Furthermore, Ou (1990) has highlighted that not only profit figures but also non-profit data in financial reports are crucial in decision making. As per the findings of his study, percentage growth in the inventory/total assets, percentage growth in the net sales/total assets, change in dividends per share relative to that of the previous year, percentage growth in depreciation expense, percentage growth in the capital expenditure/total assets ratio with one year lag, accounting rate of return, and change in rate of return relative to the previous year are some of the information which can be used to measure the bankruptcy of firms. 


\section{Methodology}

Precisely in this section, conceptual framework is addressed and operationalization is performed to identify the hypotheses then on. Moreover, sample, sampling procedure, and data collection methods are analysed.

As Young and Wang (2010) mentioned Altman's model considers the risk in multi levels. Specifically it concerns all aspects of financial statement under five categories. However, it is problematic that the contribution of financial statements to identify the business risk. Aligning with this, study focuses on examining the impact of business performance to identify the risk level of manufacturing companies.

According to the findings of Altman (1968), the Z-score can be calculated by using the different weights to the ratios.

$\mathrm{Z}=1.2 \mathrm{X} 1+1.4 \mathrm{X} 2+3.3 \mathrm{X} 3+0.6 \mathrm{X} 4+1.0 \mathrm{X} 5$

\section{Figure 1: Conceptual Framework}

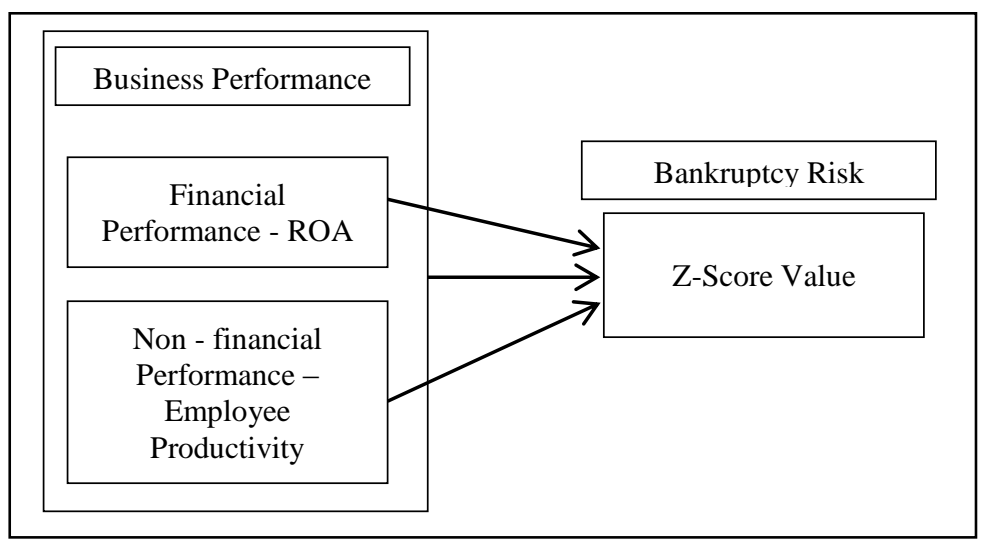

Source: Author Constructed

According to the conceptual framework (Figure 1), business performance is the independent variable, which is two folded as financial performance and non-financial performance. Return on Asset (ROA) has concerned as the proxy variable for financial performance while employee productivity is the proxy variable for the non-financial performance. When 
measuring financial performance, most of the research has been utilized profitability ratios such as ROA in order to emphasise the financial viability of the business (Evans, 2004, as cited in Cohen, Thiraios \& Kandilorou, 2008 and Wang \& Chang, 2005). At the same time, Byus and Lomerson (2004) have emphasized that, productivity ratios are towards the nonfinancial performance and those have been derived by considering the value addition. In line with the conceptual framework, dependent variable is the bankruptcy risk where Z-score has concerned as the proxy variable along with the ratios of profitability, liquidity, and gearing.

The Table 1 presents the operationalization of study variables.

Table 1: Operationalization of Variables

\begin{tabular}{lll}
\hline \multicolumn{1}{c}{ Indicators } & \multicolumn{1}{c}{ Definition } & \multicolumn{1}{c}{ Ratio } \\
\hline ROA & $\begin{array}{l}\text { A ratio reflects the total } \\
\text { earnings from total assets. }\end{array}$ & $\begin{array}{l}\text { Net income after tax / } \\
\text { Average total asset }\end{array}$ \\
\hline $\begin{array}{l}\text { Productivity per } \\
\text { Employee }\end{array}$ & $\begin{array}{l}\text { Contribution of employees for } \\
\text { sales }\end{array}$ & $\begin{array}{l}\text { Net sales/ } \\
\text { Number of employees }\end{array}$ \\
\hline $\mathrm{X}_{1}$ & Measure the liquidity level & $\begin{array}{l}\text { Working capital/ Total } \\
\text { assets }\end{array}$ \\
\hline $\mathrm{X}_{2}$ & Earnings of the company & $\begin{array}{l}\text { Retained earnings/ } \\
\text { Total assets }\end{array}$ \\
\hline $\mathrm{X}_{3}$ & Concern about capital & EBIT/Total Assets \\
\hline $\mathrm{X}_{4}$ & Measure the debt to equity & $\begin{array}{l}\text { MV of equity/BV of } \\
\text { Liabilities }\end{array}$ \\
\hline $\mathrm{X}_{5}$ & & Sales/Total assets \\
\hline
\end{tabular}

Source: Altman, 1968

According to the conceptual framework, three relationships can be identified from the model as follows.

H1: There is a direct relationship between business performance and bankruptcy level

H2: There is a direct relationship between financial performance and bankruptcy level

H3: There is a direct relationship between non-financial performance and bankruptcy level 
This study has concerned about 26 listed manufacturing companies under the CSE. However, in the study of Sandin and Porporato (2007), have selected their sample from Buenos Aires Stock Exchange and it consisted around 100 listed companies. Further, the sample was selected based on the listing rather than market capitalization or size. Importantly this expresses the validity of selected listed companies under the stock exchange.

Annual reports of 26 manufacturing companies have been analysed to collect the data for 10 years from 2004 to 2013. Panel data is utilised for the study with 260 data points. Specifically, data was analysed through e-views 6 software which is discussed in the next section.

\section{Data Analysis and Findings}

More specifically this section focuses on descriptive statistics, unit root tests, and correlation as well as regression analysis in order to analyse the data and check the hypothesis.

\section{Descriptive Statistics of the Study}

According to the descriptive statistics of dependent variable (Figure 2), mean value of the $\mathrm{Z}$-score is 3.037 , which is quite fair number since $\mathrm{Z}$-score value should be greater than three if the company is in the safe zone. However, Median value comparably low while Jarque Bera has a higher value of 3721.12 while reveal that data has high reliability with the zero probability. Furthermore, Skewness is positive which indicates the longer right tail of the histogram while Kurtosis of 20.43 derives higher Lapto Kurtosis since value is greater than three. 
Figure 2: Descriptive Statistics of ZSCORE

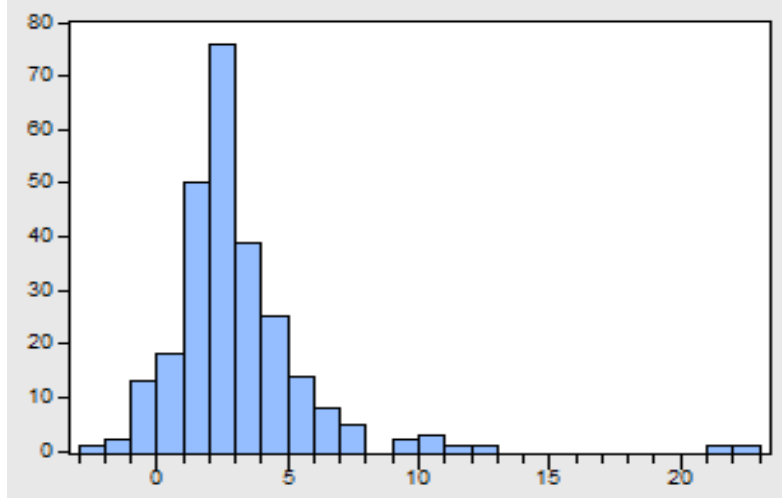

Series: ZSCORE

Sample 20042013

Observations 260

Mean

Median

3.037172

Maximum

2.471023

Minimum $\quad-2.389963$

Std. Dev. $\quad 2.755930$

Skewness $\quad 3.139447$

Kurtosis $\quad 20.43744$

Jarque-Bera $\quad 3721.128$

Probability $\quad 0.000000$

Source: Survey Data

As descriptive statistics of ROA (Figure 3), which is an independent variable, explains that Mean value of ROA is 10 per cent while Median is 5 per cent, which shows a quite difference. The Jarque Bera value is 486889 with zero probability emphasizing the high reliability of data. Moreover, Skewness is positive and higher peakness can be seen in the histogram.

\section{Figure 3: Descriptive Statistics of ROA}

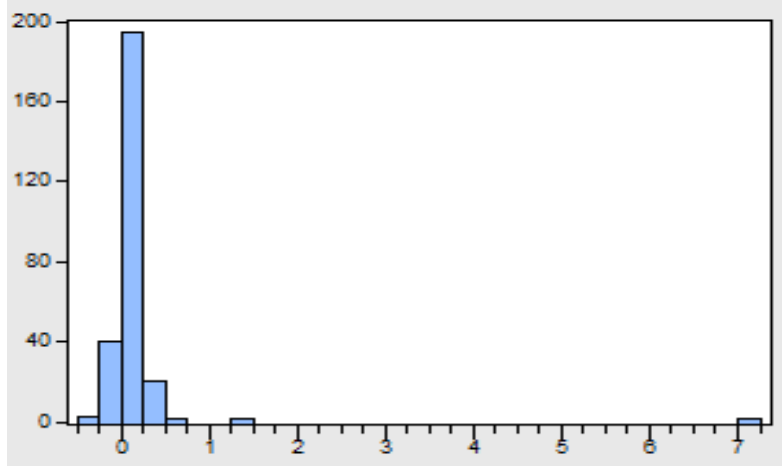

\begin{tabular}{|c|c|}
\hline \multicolumn{2}{|c|}{$\begin{array}{l}\text { Series: ROA } \\
\text { Sample } 20042013 \\
\text { Observations } 260\end{array}$} \\
\hline Mean & 0.100272 \\
\hline Median & 0.053736 \\
\hline Maximum & 7.056716 \\
\hline Minimum & -0.279469 \\
\hline Std. Dev. & 0.454365 \\
\hline Skewness & 13.95152 \\
\hline Kurtosis & 213.1549 \\
\hline Jarque-Ber & 486889.5 \\
\hline Probability & 0.000000 \\
\hline
\end{tabular}

Source: Survey Data

Specifically, descriptive statistics for productivity (Figure 4) also explains the high reliability of data with 8878 Jarque Bera value along with zero probability where data is normally distributed. Further positive 
Skewness can be seen with longer right tail in the histogram and along with a higher Kurtosis value.

\section{Figure 4: Descriptive Statistics of Productivity}
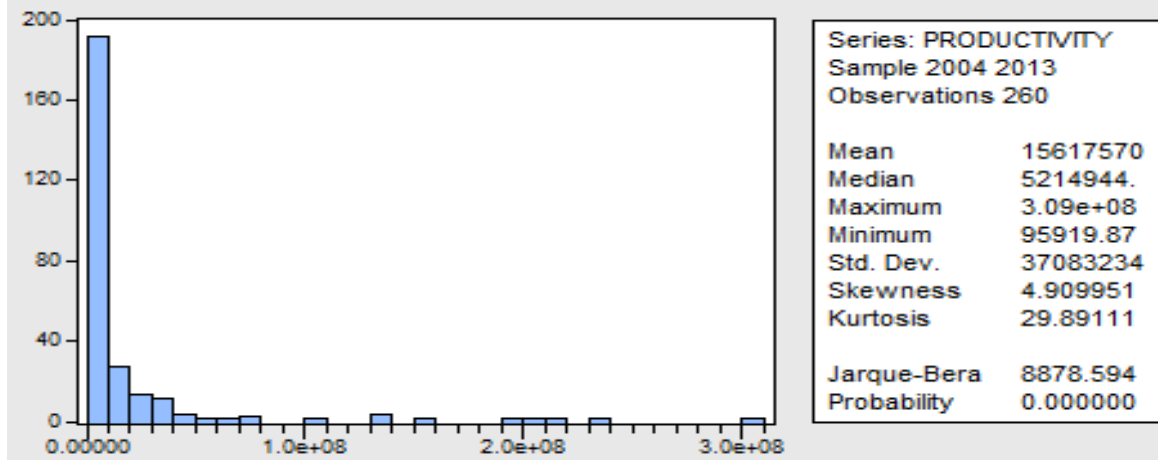

Source: Survey Data

Moreover, all tree variables in the model represent reliable data with high validity as per descriptive statistics.

\section{Results of Unit Root Test}

More precisely this study has utilized panel data and Unit Root Test was performed to test whether there is a unit root problem. However, trend has been checked prior to the Unit Root test and revealed that there is no trend for all three variables since probability values are greater than 0.05 .

According to the given results the dependent variable of which Z-score is stationary, where Mean, Variance, and Auto Correlation do not change overtime. Therefore, there is no unit root problem where probability value also less than 0.05 .

Table 2: Unit Root Test on ZSCORE

\begin{tabular}{ccc}
\hline Method & Statistics & Prob. \\
\hline Levin, Lin and Chu t* & -2.64 & 0.00 \\
\hline
\end{tabular}

Source: Survey Data 
Similarly, independent variable which is ROA also a stationary data series with zero probability. Therefore, there is no unit root problem where probability value also less than 0.05 .

Table 3: Unit Root Test on ROA

\begin{tabular}{lcc}
\hline \multicolumn{1}{c}{ Method } & Statistics & Prob. \\
\hline Levin, Lin \& Chu t* & -15.06 & 0.00 \\
\hline Source: Survey Data & &
\end{tabular}

However, the second independent variable is non-stationary where it has been converted to first difference to perform the tests further in e-views. Similarly, other variables also converted to first difference since one variable is non-stationary.

Table 4: Unit Root Test on Productivity

\begin{tabular}{ccc}
\hline Method & Statistics & Prob. \\
\hline Levin, Lin \& Chu t* & 0.98 & 0.84 \\
\hline Source: Survey Data & &
\end{tabular}

Table 5: Unit Root Test on Productivity First Difference

\begin{tabular}{lcc}
\hline \multicolumn{1}{c}{ Method } & Statistics & Prob. \\
\hline Levin, Lin \& Chu t* & -3.08 & 0.00 \\
\hline Source: Survey Data & &
\end{tabular}

Correlation has been tested in order to check whether there is a strong relationship among independent variables. According to the correlation results, Table 6, two independent variables are not correlated and both of them can be used in the model.

Table 6: Correlation Results

\begin{tabular}{lcc}
\hline & DROA & DPRODUCT \\
\hline DROA & 1.00 & -0.00 \\
DPRODUCT & -0.00 & 1.00 \\
\hline Source: Survey Data & &
\end{tabular}

Source: Survey Data

According to the conceptual framework, financial performance which is proxied by ROA, can be tested with Z-score to present whether there is a 
relationship with bankruptcy level. As per Altman's model Z-score should be greater than three and ROA shows a positive relationship with $\mathrm{Z}$ value which is a good indicator people who refer the financial performance of the annual reports. Further, probability is zero while statistics also represent value greater than 1.96 and Durbin Watson statistics also represent a fair value.

\section{Table 7: Regression Results}

\begin{tabular}{lrlll}
\hline \hline \multicolumn{1}{c}{ Variable } & Coefficient & Std. Error & t-Statistic & Prob. \\
\hline \hline \multicolumn{1}{c}{ C } & 0.051910 & 0.149289 & 0.347719 & 0.7284 \\
\multicolumn{1}{c}{ DROA } & 3.031015 & 0.314680 & 9.632052 & 0.0000 \\
\hline \hline R-squared & 0.285662 & Mean dependent var & -0.044039 \\
Adjusted R-squared & 0.282583 & S.D. dependent var & 2.690171 \\
S.E. of regression & 2.278587 & Akaike info criterion & 4.493498 \\
Sum squared resid & 1204.534 & Schwarz criterion & 4.523031 \\
Log likelihood & -523.7393 & Hannan-Quinn criter. & 4.505406 \\
F-statistic & 92.77643 & Durbin-Watson stat & 3.082800 \\
Prob(F-statistic) & 0.000000 & & \\
\hline \hline
\end{tabular}

Source: Survey Data

Specifically, non-financial performance and bankruptcy level also represent a relationship with zero probability and t-statistics. However, the relationship is negative which indicates that employee productivity is negatively affected. Further as per statistics, the coefficient value is also very less while $\mathrm{R}$-squared is around 20 per cent. 
Table 8: Regression Results on Non-financial Performance and Bankruptcy Level

\begin{tabular}{lrlll}
\hline \hline \multicolumn{1}{c}{ Variable } & Coefficient & Std. Error & t-Statistic & Prob. \\
\hline \hline \multicolumn{1}{c}{ C } & -0.051633 & 0.157653 & -0.327514 & 0.7436 \\
\multicolumn{1}{c}{ DPRODUCTIVITY } & $-5.10 \mathrm{E}-08$ & $6.70 \mathrm{E}-09$ & -7.612091 & 0.0000 \\
\hline \hline R-squared & 0.199845 & Mean dependent var & -0.044039 \\
Adjusted R-squared & 0.196396 & S.D. dependent var & 2.690171 \\
S.E. of regression & 2.411576 & Akaike info criterion & 4.606948 \\
Sum squared resid & 1349.242 & Schwarz criterion & 4.636481 \\
Log likelihood & -537.0129 & Hannan-Quinn criter. & 4.618855 \\
F-statistic & 57.94392 & Durbin-Watson stat & 2.177714 \\
Prob(F-statistic) & 0.000000 & & \\
\hline \hline
\end{tabular}

Source: Survey Data

Table 9: Regression Results on Business Performance and Bankruptcy Level

\begin{tabular}{lrllr}
\hline \hline \multicolumn{1}{c}{ Variable } & Coefficient & Std. Error & t-Statistic & Prob. \\
\hline \hline C & 0.044064 & 0.127182 & 0.346469 & 0.7293 \\
DROA & 3.022048 & 0.268078 & 11.27304 & 0.0000 \\
DPRODUCTIVITY & $-5.08 \mathrm{E}-08$ & $5.39 \mathrm{E}-09$ & -9.416841 & 0.0000 \\
\hline \hline R-squared & 0.483816 & Mean dependent var & -0.044039 \\
Adjusted R-squared & 0.479347 & S.D. dependent var & 2.690171 \\
S.E. of regression & 1.941127 & Akaike info criterion & 4.177152 \\
Sum squared resid & 870.4022 & Schwarz criterion & 4.221451 \\
Log likelihood & -485.7268 & Hannan-Quinn criter. & 4.195014 \\
F-statistic & 108.2576 & Durbin-Watson stat & 2.605657 \\
Prob(F-statistic) & 0.000000 & & & \\
\hline \hline
\end{tabular}

Source: Survey Data 


\section{Conclusion, Discussion, and Implications}

This study focused on the problems faced by the investors and managers when making decisions about companies prior to the introduction of Altman's model. Specifically, they had a problem of identifying the bankrupt companies in advance and real status of the companies. As a solution, Altman has developed the Z-score model along with the MDA, which focused on five areas of a company. Thereafter, lots of industries were benefited and people could make their decisions with less risk since they were able to predict the risk. Importantly, this study focused on Z-score value and the relationship with the business performance. Importantly, the study found that business performance results affect the bankruptcy level, which can be identified from the annual reports. Furthermore, financial information is more important than non-financial information to predict the bankruptcy risk, which is a major finding. Similarly, Gunathilake (2014) revealed that Altman model is showing more accurate and significant results in identifying the financial distress.

More precisely, the study found that there is a positive significant relationship between bankruptcy risk and financial performance. Importantly, those conclusions were arrived at 5 per cent significant level with considerably acceptable coefficient of determination. Similar to the findings of Nanayakkara and Azzez (2015) and Samarakoon and Hasan (2003), this study also proves that Sri Lankan manufacturing firms' bankruptcy level can be predicted through the Z-score model. Similar to the findings of Ou (1990), this study also highlights a negative but significant relationship between non-financial performance and bankruptcy level in Sri Lankan manufacturing firms.

The result of the study will benefit to many stakeholders in different ways. Specially, investors and current shareholders can easily use their annual reports and can find out the best manufacturing firms to invest. Further, managers and directors can evaluate and predict their company status using ratios and can take necessary corrective actions if needed. Furthermore, relevant authorities such as audit firms, governing bodies and government can easily predict the firm's future and help firms to overcome such bankruptcy situations. Moreover, they can educate public on these 
relationships and these awareness and early cure of the problems will make sure the stability of the economy.

\section{Limitations and Future Studies}

According to the study of Sandin and Porporato (2007), it is evident that ratio analysis is questionable and has some confused points as a methodology. However, this study also followed the same methodology. Therefore, it is vital to use different models and predict the bankruptcy behaviour which will help to generate better conclusion in future. Further, the future studies could be carried out in this area in different industrial categories in order to check the validity of the model.

Future research can be carried out by incorporating more qualitative factor to the model which affect to identify the bankruptcy level since information provide from the annual reports are not quite sufficient for decision making on companies in the current context.

\section{Acknowledgement}

This paper was presented at the 14th International Conference on Business Management (ICBM) held at Taj Samudra Hotel on $8^{\text {th }}$ December, 2017. We would like to acknowledge the reviewers and other academics for their valuable comments and guidance in improving this research paper.

\section{References}

Abor, J., Saprong- Kumankoma, E., Fiawoyife, E., \& Osei, K. A., (2009). Risk exposure and financial policy. Journal of Economic Studies, 36(2), 195-211.

Altman, E. I. (1968). Financial ratios, discriminant analysis and prediction of corporate bankruptcy. The Journal of Finance, 8(4), 589-609.

Altman, E. I., Haldeman, R. G., \& Narayanan, P. (1977). A new model to identify bankruptcy risk of corporations. Journal of Banking and Finance, 1, 29-54.

Appiah, K. O., \& Abor, J. (2009). Predicting corporate failure; some empirical evidence from UK. Benchmarking: An International Journal, $16(3), 432-444$. 
Bum, J. K. (2007). Bankruptcy prediction: Book value or market value? Paper presented at the Asia Pacific Risk and Insurance Association Annual Meeting, Taipei City, Taiwan. Retrieved from http:// www.rmi.nccu.edu.tw/apria/docs.

Byus, K., \& Lomerson, W. L. (2004). Consumer originated value. Journal of Intellectual Capital, 5(3), 464- 477.

Cohen, S., Thiraios. D., \& Kandilorou, M. (2008). Performance parameters interrelations from a balanced scorecard perspective: An analysis of Greek companies. Management Auditing Journal, 23(5), 485- 503.

Colombo Stock Exchange. (2009). CSE fact book, Colombo CSE.

Gnanaweera, K. A. K. (2011). A study of bankruptcy level in Sri Lanka (Unpublished masters' thesis). University of Sri Jayewardenepura, Sri Lanka.

Gunathilaka, C. (2014). Financial Distress Prediction: A Comparative Study of Solvency Test and Z-Score Models with Reference to Sri Lanka. IUP Journal of Financial Risk Management, 11(3), 39-51.

Lee, T., \& Yeh, Y. (2004). Corporate governance and financial distress: Evidence from Thaiwan. Corporate Governance: An International Review, 12(3), 378-388.

Nanayakkara, K. G. M., \& Azeez, A. A. (2015). Predicting corporate financial distress in Sri Lanka: An extension to Z-Score model. International Journal of Business and Social Research, 5(3), 41-56.

Ong, S. W., Yap., V. C., \& Khong, R. W. L. (2011). Corporate failure prediction; Study of public listed companies in Malaysia. Managerial Finance, 37(6), 553-564.

$\mathrm{Ou}, \mathrm{J}$. (1990). The information content of non-earnings accounting numbers as earnings predictors. Journal of Accounting Research, 28(1), 2-21.

Samarakoon, L. P., \& Hasan, T. (2003). Altman's Z-Score models of predicting corporate distress: Evidence from the emerging Sri Lankan stock market. Journal of the Academy of Finance, 1, 119-125.

Sandin, A. R., \& Porporato, M. (2007). Corporate bankruptcy prediction models applied to emerging economies. International Journal of Commerce and management, 17(4), 295-311.

Thusyanthi, R., \& Yogendrarajah. R. (2016). Factors influencing companies' leverage: Evidence from listed manufacturing companies in Sri Lanka. Paper presented at the fifth Annual International Research Conference, Oluvil, Sri Lanka. 
Young, A., \& Wang, y. (2010). Multi risk level examination of going concern modification. Managerial Auditing Journal, 25(8), 756-791. 